
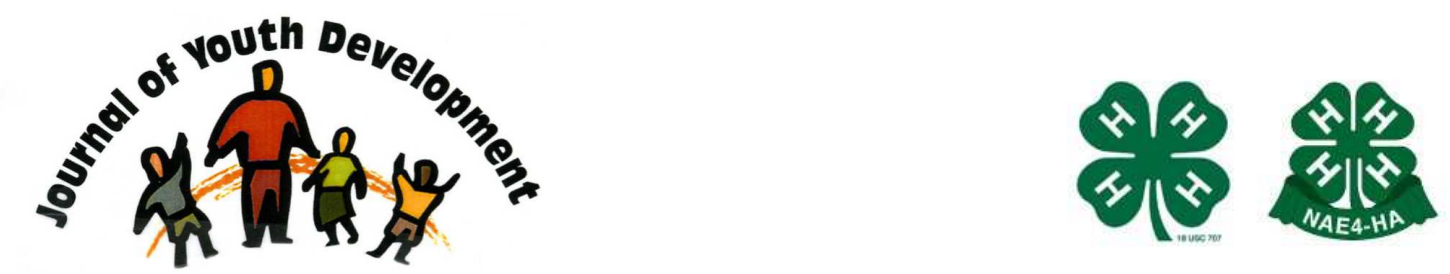

Bridging Research \& Practice

\title{
The Many Faces, Features and Outcomes of Youth Engagement
}

\author{
Rebecca N. Saito \\ University of Minnesota Extension \\ Center for Youth Development \\ saito015@umn.edu
}

Theresa K. Sullivan

Search Institute 


\title{
JOURNAL OF YOUTH DEVELOPMENT \\ bridging research and practice

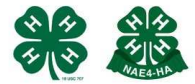

Volume 6, Number 3, Fall 2011

Article 110603FA007

\section{The Many Faces, Features and Outcomes of Youth Engagement}

\author{
Rebecca N. Saito \\ University of Minnesota Extension Center for Youth Development \\ Theresa K. Sullivan \\ Search Institute
}

\begin{abstract}
Civic engagement, experiential education, positive youth development, youth leadership, service-learning: what is it about these programmatic models that account for their popularity and impact over decades? What's at the core, how are they similar and different, and what differential impacts and benefits might various types or forms of youth engagement affect? The lack of consensus on conceptual frameworks and definitions of youth participation and engagement has been identified as one of the issues plaguing the field and restricting progress of youth engagement research and practice (O'Donoghue, Kirshner \& McLaughlin, 2002). The authors present a conceptual framework called the Rings of Engagement that captures the myriad ways in which people think about youth engagement. The literature on the benefits and outcomes of each ring or type of youth engagement is highlighted. The authors conclude with recommendations for further research which will guide training, stakeholder-driven communication tools created to garner support, ways to act locally while working at the intermediary level to provide the supports necessary to promote and support youth engagement.
\end{abstract}

\section{Introduction}

The concept of youth engagement has been an enduring, yet evolving feature in the landscape of community-based youth development work. It has been called many things over the years: youth leadership, civic engagement, youth participation, youth voice, to name but a few. And it means very different things to different people.

For some, the focus of youth engagement is on ensuring that young people participate in high quality programs. For others, youth engagement is about helping young people find activities they are passionate about. Another notion of youth engagement emphasizes the value of youth 
voice and input, or having a say in matters that affect them. Some consider youth and adults collectively sharing decision-making power and authority to be a hallmark of youth engagement. And researchers and practitioners largely agree that all these forms of youth engagement, done well, are good for young people, programs and communities (Sullivan, 2011).

So what do these different types of youth engagement have in common? What's at the core that makes them so attractive and enduring? In what ways do they overlap and how do they differ? What outcomes can they affect? And what will it take to ensure that young people, especially those in communities and families with limited resources, experience multiple engaging programs, experiences and relationships? These questions are at the heart of this article.

Our effort to unravel and identify the many threads and forms of youth engagement is motivated by the need to move forward a comprehensive agenda that advances understanding, support and promotion of quality youth engagement opportunities. Such an agenda could create communities in which young people's strengths and assets are recognized, utilized and built upon through multiple developmentally-linked opportunities to connect and contribute.

While it is clear from the literature that youth engagement is important and beneficial for all young people, this article pays extra attention to the needs of older youth, age 14 and above, particularly those that live in lower-income families and communities. Participation in youth programs is lowest for these teens (Lochner, Allen \& Blyth, 2009), and as they get older they require a broader range of opportunities that match their developmental needs for expanding horizons, autonomy, challenge, voice and decision-making.

We present the Rings of Youth Engagement (Figure 1) as a conceptual framework for organizing this chapter. We describe and summarize the benefits and impacts associated with each of the four types of youth engagement in the model. We conclude with a discussion of enduring challenges and possible next steps to ensure that all youth have the opportunities to engage in the programs and activities that they want and need.

Figure 1

Rings of Engagement

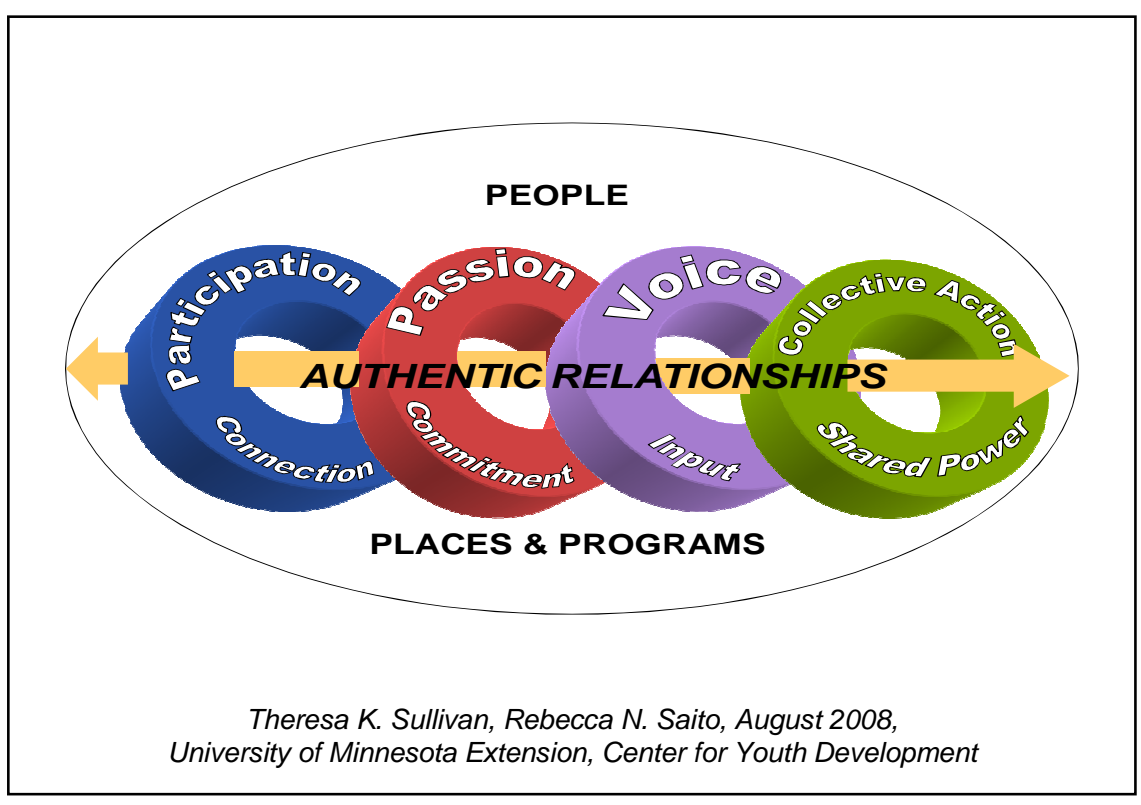




\section{Conceptual Framework: Rings of Engagement}

To bridge the various definitions and understandings of youth engagement, Sullivan (2011) designed a study to conceptualize, convey and stimulate alternative ways of thinking about youth engagement by integrating learning from scientific research, practice-based literature, and the experiences of practitioners and youth.

This research process both informed and was informed by Sullivan and Saito's conceptual theory of differential yet related aspects of engagement. The "Rings of Engagement" framework (see Figure 1) visualizes four critical dimensions of youth engagement: participation, passion, voice, and collective action. All are dependent on a core of authentic relationships and a context of engaging people, places and programs. The latter is represented by the fifth ring surrounding the other four.

Benefits of participation are strengthened through opportunities for connection to positive people and places. Passion includes commitment to ongoing growth and development in a particular area of pursuit. Voice requires opportunities for youth to have input into decisions that affect them. Collective action includes shared power and decision-making authority among youth and adults.

Sullivan's study involved

1) an extensive review of the literature,

2) interviews, focus groups and program observations with youth and adults at four case study sites,

3) ten half-day regional forums and two facilitated one-hour discussions with adult practitioners, and

4) video-taped discussion and interviews with experienced "master practitioners" who mentor others in the effective practice of youth engagement.

Practitioners in Sullivan's study and the youth development literature (Blyth, 2006: Eccles et al., 1993) asserted the importance of all four types of engagement for the well-being of youth and society. Practitioners said they do not see the rings as hierarchical. Nor do they see them representing successive stages in which youth need to have experienced one in order to be "ready" for another. Experiences in any of the rings of engagement can lead to opportunities, interest and/or readiness to engage in other ways. See figure 2 for a brief overview of each of the rings. 
Figure 2

Overview of the Rings of Engagement

\begin{tabular}{|c|c|c|c|}
\hline & DEFINITION & $\begin{array}{l}\text { BENEFITS/ } \\
\text { OUTCOMES }\end{array}$ & $\begin{array}{l}\text { BOOSTING YOUTH ENGAGEMENT } \\
\text { WITHIN PROGRAMS }\end{array}$ \\
\hline $\begin{array}{l}\text { PARTICI- } \\
\text { PATION }\end{array}$ & $\begin{array}{l}\text { Young people } \\
\text { participate in formal, } \\
\text { informal and non-formal } \\
\text { activities offering: } \\
\text { opportunities to connect } \\
\text { with positive people and } \\
\text { places; and challenges/ } \\
\text { supports that promote } \\
\text { growth and } \\
\text { development. }\end{array}$ & $\begin{array}{l}\text { - Psychosocial development } \\
\text { - Academic achievement } \\
\text { - Physical fitness } \\
\text { - Mastery of skills } \\
\text { - Reduced risk taking } \\
\text { - Positive identity } \\
\text { - Civic participation } \\
\text { - Gateway to other engagement }\end{array}$ & $\begin{array}{l}\text { - Assess and market existing youth programs } \\
\text { - Repportunities } \\
\text { - } \text { Remove barriers to participation } \\
\text { fun, time with friends, develop skills, build } \\
\text { resume, accomplish something that matters) } \\
\text { and create opportunities that appeal to their } \\
\text { interests. }\end{array}$ \\
\hline PASSION & $\begin{array}{l}\text { Becoming engrossed in } \\
\text { or passionate about } \\
\text { something, based on } \\
\text { experiencing the activity } \\
\text { itself as rewarding, } \\
\text { regardless of outcome } \\
\text { or external rewards. } \\
\text { Marked by high levels } \\
\text { of attention, } \\
\text { concentration, } \\
\text { enthusiasm and } \\
\text { commitment. }\end{array}$ & $\begin{array}{l}\text { - Life satisfaction } \\
\text { - Motivation for continued learning, } \\
\text { practice, growth and development } \\
\text { - Social approval, gateway to a } \\
\text { supportive community } \\
\text { - Contributions to social good } \\
\text { - Academic achievement }\end{array}$ & 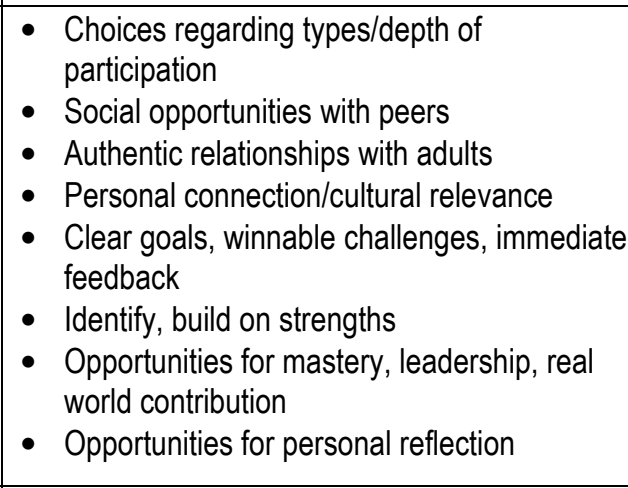 \\
\hline VOICE & $\begin{array}{l}\text { Young people have } \\
\text { opportunities to voice } \\
\text { their ideas and have } \\
\text { input into programs, } \\
\text { policies and practices } \\
\text { that affect them. }\end{array}$ & $\begin{array}{l}\text { - Enhanced sense of efficacy/agency } \\
\text { - Problem-solving, communication, } \\
\text { advocacy skills } \\
\text { - Academic achievement } \\
\text { - Improved programs that get others } \\
\text { participating, passionate }\end{array}$ & $\begin{array}{l}\text { - Authentic opportunities to be heard, have an } \\
\text { impact } \\
\text { - Avoid tokenism } \\
\text { - Report back with impact of youth ideas on } \\
\text { policy, practice } \\
\text { - Build new perspectives/skills for youth and } \\
\text { adults } \\
\text { - Active listening } \\
\text { - Appreciating diverse strengths } \\
\text { - Facilitating effective conversations }\end{array}$ \\
\hline $\begin{array}{l}\text { COLLEC- } \\
\text { TIVE } \\
\text { ACTION }\end{array}$ & $\begin{array}{l}\text { Youth and adults share } \\
\text { decision-making } \\
\text { authority as they work } \\
\text { together to: a) achieve } \\
\text { shared goals within } \\
\text { systems; and/or } \\
\text { b) change or create } \\
\text { new systems. }\end{array}$ & $\begin{array}{l}\text { - Positive civic identity } \\
\text { - Sense of collective efficacy } \\
\text { - Collaborative planning, decision- } \\
\text { making, implementation skills } \\
\text { - Critical social consciousness, } \\
\text { analysis } \\
\text { - Social/political change skills } \\
\text { - Ongoing civic engagement } \\
\text { - Organization-community change }\end{array}$ & $\begin{array}{l}\text { - } \text { Identify shared passions } \\
\text { - Broaden perspectives re: youth/adult roles, } \\
\text { relationships } \\
\text { - } \text { Transparency about roles, authority, } \\
\text { responsibilities } \\
\text { - Develop and utilize collaborative processes, } \\
\text { skills } \\
\text { - Develop knowledge/skills with respect to } \\
\text { - } \text { sociopolitical issues/change } \\
\text { - } \text { within the collective } \\
\text { - Stay flexible as issues/dynamics change }\end{array}$ \\
\hline
\end{tabular}

A recent study by Search Institute (Scales, Roehlkepartain, \& Benson, 2010) found that the more types of youth engagement opportunities youth experience, the better off they will be. Youth who were highly engaged did better on academic, psychological, social-emotional and 
behavioral outcomes. Unfortunately, only seven percent of youth in their study experienced high levels of all types of engagement.

Three important ideas were woven throughout the literature and practitioners' notions about all the forms of youth engagement:

1. Youth as Contributors and Leaders - One fundamental thread through all the forms of youth engagement is the recognition and belief that young people have skills, perspectives and expertise that can be tapped to help make activities and programs relevant, engaging and effective at promoting growth and development.

2. Developmental Perspectives - As children become teenagers, the kinds of programs and opportunities they need and want change. Adolescents need to develop their sense of identity and autonomy in the framework of ever-expanding social contexts; practice making important, impactful decisions; and learn attitudes and habits that will impact engagement throughout youth and adulthood. These normal developmental needs influence the types of programs and opportunities to which older adolescents are attracted. Programs that offer opportunities for voice, decision-making, connection to a broader community and action that meaningfully impacts that community fit the needs and interests of this group.

3. Reciprocal Relationships at the Core - Engagement depends on ongoing, authentic relationships between youth and adults. While youth engagement is often thought of as a process of adults engaging youth, quality youth engagement involves youth and adults engaging with each other in ways that benefit both.

\section{Participation}

Young people participate in a range of programs and opportunities that enable them to connect with positive people and experiences, through which they learn and develop new skills. This includes formal after-school, evening and weekend youth programs in non-profit youth or community organizations; public parks, schools, libraries; and various religious, arts, sports and civic organizations. Quality youth programs are described by some young people as "second homes" (Hirsch, 2005, pg. 41) where they develop supportive relationships with staff and other youth, try on new roles and identities (Konopka, 1973), learn new skills and explore new ideas and experiences. While the activities, venues and specific target outcomes vary greatly, high quality youth development programs can provide intentional, developmentally appropriate opportunities for young people to grow and develop that occur outside the formal school day (Blyth, 2006; Walker, 2006).

\section{Benefits of Participation}

Youth reap a wide range of positive developmental outcomes through participation, including physical health, positive psychosocial development, enhanced academic achievement, mastery of specific skills, reduction in violence and risk-taking behavior, and positive identity development (Bronfenbrenner, 1979; Eccles \& Gootman, 2002; Pittman, Martin, \& Williams, 2007; Resnick et al., 1997; Scales, Benson, Leffert, \& Blyth, 2000; Scales \& Leffert, 1998; Walker, 2006; Weiss, Little, \& Bouffard, 2005; Zeldin, Camino \& Calvert, 2007). Scales et al. (2010) found that 15-year-olds who scored high on a relationships and opportunities index (measuring opportunities for participation and supportive relationships) were much more likely than low scorers to: work up to their ability at school (60\% vs. $25 \%$ ); have a grade point 
average of 3.5 or higher ( $73 \%$ vs. 53\%); have a sense of purpose and hope for their future (59\% vs. $17 \%$ ); and have a positive sense of their ethnic identity (56\% vs. $15 \%$ ).

Youth explore through participation ideas about who they can be and who they want to be as a member of the broader community, while building capacities, commitments, and social connections (Kahn \& Westheimer, 2003) they need to succeed in their chosen roles. Flanagan (2003) found that participation, especially in diverse groups, can build a sense of belonging and social trust, a belief that "most people are fair, helpful, and trustworthy" (p. 167). She also found it widens the sphere of others to whom one feels a sense of connection and responsibility. And those who participate in adolescence are more likely to participate in community organizations and institutions throughout their lives (Hart, Donnelly, Youniss \& Atkins, 2007; Youniss \& Hart, 2005).

Only 19 percent of participants in the Scales, et al (2010) study scored high on their relationships and opportunities index. If youth don't participate, they cannot reap the benefits outlined above (Herrera \& Arbreton, 2003; Kennedy, Wilson, Valladres, \& Bronte-Tinkew, 2007). And in order to participate, young people need opportunities to do so.

\section{The Participation Gap}

There is a growing awareness and evidence that rates of participation in youth development programs and opportunities drop around age 12 or 13 and remain low through the rest of adolescence (Duffett \& Johnson, 2004; Farrell, 2008; Herrera \& Arbreton, 2003; Lauver, Little, \& Weiss, 2004; Simpkins, Little, \& Weiss, 2004; Sipe \& Ma, 1998; Yohalem, Wilson-Ahlstrom, \& Pittman, 2004,). Participation rates are especially low for youth who come from families and communities with lower incomes and opportunities (Littel \& Wynn, 1989; Lochner, Allen, \& Blyth, 2009; Pittman, Wilson-Ahlstrom, \& Yohalem, 2003; Saito, Benson, Blyth, \& Sharma, 1995). Freeman (2009) argues that the opportunities for experiencing and learning about citizenship are "highly unequal among youth of different backgrounds, cultures, race, and socioeconomic status and therefore unique and different strategies must be employed to effectively address the issues and concerns necessary for highly effective youth civic engagement" (p.2).

\section{Passion}

Passionate engagement happens when youth become engrossed in some activity. It is marked by high levels of attention, concentration, enthusiasm and commitment. The latter can be seen in high levels of effort and persistence, as well as pride in success. When youth are passionate about an activity, it becomes rewarding in its own right, regardless of the outcome or external rewards like social approval, money or power (Nakamura, 2001; Weiss et al., 2005). When youth find an activity with which they engage in this way, Benson and Scales (2007) call it their "spark." Nakamura calls it "vital engagement." Csikszentmihalyi (1997) calls it "flow," a state he and others assert we can find through any activity we find enjoyable, worth doing, challenging, and at which we can improve over time (Damon, 2008).

In a Search Institute study of 3,500 young people and 2,000 parents, the most commonly reported youth sparks, in order of the frequency with which they were reported are: creative arts; athletics; learning an academic subject (e.g. math, science or history); reading; helping others/volunteering; spirituality/religion; a commitment to living in a specific way (e.g. with joy, passion, caring); animal welfare; and leading (Benson, 2008). 


\section{Benefits of Passion}

People who are more psychologically engaged in an activity tend to learn more (Pearce \& Larson, 2006), and not just in the activity about which they are passionate. Research has shown that young people who have identified a spark or passion are more likely than others to do well in school. In addition, youth say that pursuing their spark(s) has helped them learn new things outside of school, including skills that could help them in a career. They also reported higher levels of initiative, sense of purpose, desire to make a difference, and tended to be less driven by external rewards like fame, power, comfort and money (Csikszentmihalyi, 1975; Scales, Roehlkepartain, \& Benson, 2009, 2010).

These outcomes can lead to social approval and increased attention from supportive adults, as well as the satisfaction of mastering challenges which, in turn, motivate ongoing learning and practice (Benson \& Scales, 2007; Blyth, 2006; Csikszentmihalyi, 1975; Pearce \& Larson, 2006). When they pursue an activity over a long period of time, young people often become integrated into a community of people who engage in that activity, providing extended opportunities for indepth social connection and the development of social skills (Benson \& Scales, 2007; Minnesota Youth Engagement Case Studies, 2008; Nakamura, 2001).

\section{Voice}

Voice refers to opportunities for youth to express their ideas and have input into programs, policies and practices that affect them. While youth do not have full decision-making authority in this type of engagement, they have authentic input. This means they have the power to influence programs and policies by sharing their perspectives, information and/or making a persuasive case to adults who truly consider their ideas as they make decisions.

Youth find opportunities to voice their ideas and have input into programs and policies in a variety of ways, including: youth media (e.g. print, broadcast, internet, film); advisory boards; political advocacy; participating in surveys, interviews, focus groups; promoting ideas/products/services they value to other youth; and boycotting those they don't value (Search Institute, 2005). Some opportunities for youth voice will influence specific activities or projects within a program. Others will influence the broader policies and practices of an organization.

\section{Benefits of Youth Voice}

Organizations, communities and the young people they serve all benefit when youth have a voice. For example, when youth have a voice in the development of programs and activities, they help create programs in which they and other youth like them are more likely to participate and remain committed (Boyt \& Skelton, 1997; Pittman et al., 2007; Saito, 2006; Smith, Akiva, Arrieux, \& Jones, 2006; Walker, 2006). At the same time, youth gain new knowledge and skills when they have a voice in programs and policies that affect them. They learn about the structure and politics of organizations and institutions as they figure out how to effectively promote their interests within them. They can also develop problem-solving, communication and advocacy skills. Beyond direct learning from these experiences, youth who express their voice tend to do better overall in terms of academic achievement (Kahn \& Westheimer, 2004; Zeldin et al., 2007). 
Along the way, youth develop a sense of belonging (Flanagan, Stoppa, Syvertsen, \& Stout , 2010), as well as efficacy and agency, coming to see themselves as people who can and do make organizations and communities better places. This in turn can motivate them to continue to try to make organizations and communities better places for all (Kahn \& Westheimer, 2004; Pearce \& Larson, 2006; Zimmerman \& Campillo, 2003).

Flanagan et al. (2010) found that when they were encouraged to voice their views in school, students were more likely to act on behalf of a greater good beyond their direct self interest. For example, they were more likely to speak up if a peer was talking about doing something dangerous at school. When diverse youth voice their ideas and perspectives in the policy arena, it helps align the public agenda with the interests and concerns of a broader citizenry. It also enhances the likelihood that youth-oriented policies will achieve their intended outcomes because they are based on an understanding of the interests, values and motivations of those they are intended to serve (Boyt \& Skelton, 1997; Noguera \& Cannella, 2006).

Adults are also impacted. When youth have authentic opportunities to share their ideas, adults begin to appreciate their insights, wisdom and commitment, counteracting common adult perceptions that today's youth are academically lazy, prone to crime and violence, and uninterested in anything beyond themselves (Noguera \& Cannella, 2006). This makes it more likely that adults will continue to create new opportunities for youth to engage in this way.

\section{Collective Action}

Collective action happens when youth and adults partner to achieve common goals, sharing power and authority to make decisions along the way. Watts and Flanagan (2007) distinguish between two distinct types of youth-adult partnerships for collective action, based on the breadth of decision-making power youth and adults share. In the first type of collective action, young people have clearly defined authority to shape policy and make decisions within current systems (e.g. setting editorial guidelines and making editorial decisions for a youth magazine; or identifying goals, setting criteria and awarding a subset of a foundation's grants to youth programs). In the second, youth and adults share power to change or create new systems. This happens when youth and adults share decision making authority for overall governance of an organization or when they organize together to make things happen in the broader community.

For some, the term "collective" is associated with forgoing individual responsibility and rights in support of the collective. We use the term collective action here to represent a process of developing and sharing one's own perspectives, passions and skills while working in collaboration with others to achieve shared goals. This includes thinking critically and asserting one's own rights and responsibility to disagree with the group; as well as speaking and acting independently from the group when the group's beliefs and values do not align one's own.

Examples abound in which young people played a fundamental role as social activists and change-makers in their countries, communities, schools, neighborhoods and families (Hart, 1992; Youniss et al, 2002). They have affected policy change and influenced broad-based behavioral norms related to a wide range of issues, including education, social health, peacekeeping, and environmental protection (O'Donoghue et al. 2002). As we write this article young people around the world are driving powerful political change movements in countries like Egypt, Syria and Libya. 


\section{Benefits of Collective Action}

As with youth voice, youth, organizations and communities all benefit from collective action. Youth develop real-world problem solving and collaborative skills deemed critical for workers and citizens in the $21^{\text {st }}$ century. And, as diverse youth help to create the kind of organizations and communities in which they want to engage and contribute, they become more connected to these places, they continue to work with others to improve them, and organizations and communities come to more closely reflect the values and meet the needs of all youth.

Commitment to and learning from experiences in organizations and communities are enhanced when youth and adults share decision making (Innovation Center \& National 4-H, 2003; O'Donaghue et al., 2002). For some, it has been shown to increase commitment to school and college (Larson, Walker, \& Pearce, 2005). When they work together to grapple with and address environmental, social and political issues, youth and adults learn to analyze social and political power dynamics and to identify, develop and mobilize community resources to solve real-world problems (Ginwright \& Cammarota, 2006; Kahn \& Westheimer, 2004; Kirshner, 2006; Larson \& Hansen, 2005; Pittman et al., 2007; Search Institute, 2005; Watts \& Flanagan, 2007).

A shift in focus away from individual outcomes to developing a group's capacity to reach shared goals, what Watts and Flanagan (2007) call "collective human development" (p. 784), may be the greatest benefit of collective action. This includes skills for collaborative goal setting, decision-making, planning and implementation, competencies they often carry into other parts of their lives (Larson et al., 2005; Zeldin, 2004; Zeldin et al., 2007). Youth and adults learn to co-construct ideas through research, dialogue and critical thinking, negotiating the development of individual beliefs and values within, and yet still independent from those of the group (Noguera \& Cannella, 2006). Along the way, they build relationships of mutual respect which, in addition to offering emotional support, can open other doors in the community, as adults offer to write college recommendations, connect them with jobs and internships, scholarships, and other opportunities (Zeldin, 2004).

The community benefits, as noted earlier in this paper, when participation builds social trust. And yet social trust is also precursor to participation (Flanagan, 2003). Collective action provides a way for disengaged youth and adults to build trusting relationships within a group while helping to create or shape systems they can trust and in which they want to participate (Ginwright \& Cammarota, 2006; Kahn \& Westheimer, 2004; Pittman et al., 2007; Search Institute, 2005; Watts \& Flanagan, 2007; Wheeler, 2007 a\&b). Putnam, Feldstein, \& Cohen (2003) assert that the social capital built through such endeavors represents "not a comfortable alternative to social conflict, but a way of making controversy productive" (p. 3).

Past research has shown those who are engaged in this way during adolescence are more likely to continue to actively engage throughout youth and adulthood (Colby \& Damon, 1992; Haste, 2003, 2004; Kahn \& Westheimer, 2003; Pittman et al., 2007; Watts \& Flanagan, 2007; Youniss \& Hart, 2005; Youniss et al., 2002; Youniss \& Yates, 1997). As people of all age, cultural and socioeconomic groups come to believe they can help shape organizations, communities and society, and actually have opportunities to do so, these institutions will come to more closely reflect the values and meet the needs of all their members (Sirianni and Friedland, 2001; Verba, Schlozman \& Brady, 1995; Zeldin et al., 2007). 


\section{An Agenda to Increase and Advance Youth Engagement}

We know there are myriad programmatic and more organic forms of youth engagement as expressed and seen through the inclusive lens of the Rings of Engagement framework. Done well, any form of youth engagement can benefit young people, youth programs, and communities.

We also know that not nearly enough young people, particularly older youth in lower income communities and families, engage in these growth-enhancing programs, opportunities and relationships. We suggest that successful programs and opportunities will be more attractive to and retain young people ages 14 and older when they meet adolescents' natural developmental needs for experiencing increasing levels of autonomy, voice and decision-making authority in ever-broadening spaces and places.

Fortunately, no single organization has to provide all of these opportunities. If young people can find and access a range of different opportunities and relationships throughout the community, over time they can engage in different programs and places to address their changing needs. This scenario depends upon a coordinated system of useful research leading to research-based professional and product development, marketing, technology and other infrastructure systems to support communication, connection and learning.

A comprehensive agenda to promote and support youth engagement might include these five elements.

1. Useful research to deepen our understanding of the benefits of youth engagement, what it takes to do it well, and obstacles we must overcome to put into practice what we know works. Our work to date suggests the following kinds of research needs:

a. Document individual, organization and community outcomes produced by each type of engagement and how they are achieved.

b. Learn more about youth who are not participating, particularly older youth from low income families and communities, with a focus on what attracts and keeps them involved.

c. Map various pathways to participation and engagement, based on differences among youth and the communities in which they live

d. Understand the interests, needs, beliefs, assumptions and perspectives of different stakeholders (including youth, parents, program providers and policymakers); and what it will take for them to actively support youth engagement efforts.

e. Learn more about how formal and non-formal out-of-school-time programs and informal, non-programmatic (e.g., pick-up basketball, garage talent shows) youth engagement work together to produce positive youth outcomes; and how we can catalyze, support and integrate the proliferation of all these opportunities.

2. Deepen and broaden the practice of youth engagement through the development of useful training, technical assistance, coaching, peer learning, online forums, practitioner and research blogs, and other vehicles for practitioners and other stakeholders to learn from and with each other. 
3. Create effective communication and awareness-raising tools that translate research into user-friendly, stakeholder-driven products, tools and messages that pique the interest and meet the needs of a variety of audiences.

These tools can be the basis for an integrated awareness raising campaign that can be tailored to meet specific outreach needs. This would include key messages and supporting content directed toward program providers, youth workers, policymakers, youth and parents, helping each group understand how youth engagement can help them achieve goals they care about most.

4. Build system-level opportunities, resources and technology that support collaborative training, research, communication and connections across people, programs and communities.

\section{Closing Reflections}

Youth engagement is both a means to an end and an end in itself. It is expressed and experienced through various program models, yet it is more than just a method or a tool. It represents a philosophical shift in the way we think about the relationships, roles, assets, power and opportunities that can exist between young people and the adults, programs and communities that surround and include them.

The goal is to ensure that young people are surrounded by multiple, captivating, developmentally-scaffolded opportunities for engagement and leadership in programs and communities. This will require programs and organizations to look for ways to work with young people to achieve shared goals, recognizing the value and resources each brings.

Youth engagement also requires a personal commitment. Each of us has the opportunity to examine how we engage with youth in our own daily interactions where we work, learn, gather, pray and play. This represents a cultural shift in Western society, to recognize that all people, regardless of age, have strengths to offer and that young people have a right and need to walk alongside us. In the process, we will learn from each other and work together to get it right (Sullivan, 2011).

\section{References}

Benson, P., \& Scales, P. (2007). Search Institute's Ongoing Development of the Theory of Thriving, a presentation at the Healthy Communities Healthy Youth Conference in Rochester, NY, November, 2007.

Benson, P. (2008). Sparks: How Parents Can Help Ignite the Hidden Strengths of Teenagers. San Francisco: Jossey-Bass.

Blyth, D. (2006). Toward a new paradigm for youth development, in New Directions for Youth Development, 2006 (112), pp. 25-43.

Boyt, H., \& Skelton, N. (1997). The Legacy of Public Work: Educating for Citizenship, in Educational Leadership 54(5), pp. 12-17. 
Bronfenbrenner, U. (1979). The ecology of human development: experiments by nature and design. Cambridge, MA: Harvard University Press.

Colby, A., \& Damon, W. (1992). Some do care: Contemporary lives of moral commitment. New York: Free Press.

Csikszentmihalyi, M. (1975). Beyond Boredom and Anxiety. San Francisco: Jossey-Bass.

Csikszentmihalyi, M. (1997). Finding Flow: The Psychology of Engagement with Everyday life. New York: Basic Books.

Damon, W. (2008). The Path to Purpose. New York: Free Press.

Duffett, A., \& Johnson, J. (2004). All work and no play? Listening to what KIDS and PARENTS really want from out-of-school time. Public Agenda.

Eccles, J.S., \& Gootman, J.A. (Eds.). (2002). Community programs to promote youth development: Committee on community-level programs for youth. Washington, DC: National Academy Press.

Eccles, J., Midgley, C., Wigfield, A., Miller Buchanan, C., Reuman, D., Flanagan, C., et al. (1993). Development during Adolescence, in American Psychologist 48(2), pp. 90-101.

Farrell, B. (2008). Building Youth Participation. Chapter 6 in Entering Cultural Communities: Diversity and Change in the Nonprofit Arts. Rutgers University Press.

Flanagan, C. (2003). Trust, Identity, and Civic Hope, in Applied Developmental Science 7(3), pp. 165-171.

Flanagan, C., Stoppa, T., Syvertsen, A.K., \& Stout, M. (2010). Schools and Social Trust, in Handbook of Research on Civic Engagement in Youth, Sherrod, L.R., Torney-Purta, and Flanagan, C.A. (Eds). NJ: John Wiley \& Sons.

Freeman, D.M. (2009). 4-H Citizenship Mission Mandate Proposal. Unpublished manuscript. University of Minnesota Extension Center for Youth Development.

Ginwright, S., \& Cammarota, J. (2006). Introduction, in Beyond Resistance! Youth Activism and Community Change: New democratic possibilities for practice and policy for America's youth, Ginwright, S. Noguera, P. \& J. Cammarota (Eds). New York: Routledge, Taylor \& Francis Group, pp. xiii-xxii.

Hart, R. (1992). Children's Participation: from Tokenism to Citizenship. New Florence, Italy: UNICEF.

Hart, D., Donnelly, T.M., Youniss, J., \& Atkins, R. (2007). High School Community Service as a Predictor of Adult Voting and Volunteering, in American Educational Research Journal. 44(1), pp. 197-219. The online version of this article can be found at: http://aer.sagepub.com/cgi/ content/abstract/44/1/197. 
Haste, H. (2003). Moral responsibility and citizenship education, manuscript to appear in Art, Science and Morality: Creative Journeys, Wallace, D. (Ed.). NY: Plenum Press.

Haste, H. (2004). Constructing the Citizen. Political Psychology, 1 (3), pp. 413-436. Herrera, C., \& Arbreton, A.J. (2003). Increasing opportunities for older youth in after-school programs. Public/Private Ventures: Philadelphia.

Hirsch, B.J. (2005). A Place to Call Home: After School Programs For Urban Youth. New York: Teachers College Press.

Innovation Center for Community and Youth Development \& National 4-H Council. (2003). Youth in Decision-making: Research Highlights from a study on the impacts of youth and adults and organizations. MD: Innovation Center.

Kahn, J., \& Westheimer, J. (2003). Teaching Democracy: What Schools Need to Do. Phi Delta Kappan, September, 2003, pp. 34-65.

Kahn, J., \& Westheimer, J. (2004). What Kind of Citizen? The Politics of Educating for Democracy, in American Educational Research Journal, 41(2), pp 237-269.

Kennedy, E., Wilson, B., Valladares, S., \& Bronte-Tinkew, J. (2007). Improving Attendance and Retention in Out-of-School Time Programs. Child Trends.

Kirshner, B. (2006). Apprenticeship Learning in Youth Activism, in Ginwright, S., Noguera, P., Cammarota, J. (Eds.). Beyond Resistance! Youth Activism and Community Change. New York: Routledge, pp. 37-57.

Konopka, G. (1973). Requirements for Healthy Development of Adolescent Youth. Adolescence 8(31): 1-26.

Larson, R., \& Hansen, D. (2005). The development of strategic thinking: Learning to impact human systems in a youth activism program. Human Development 48: 327-349.

Larson, R., Walker, K., \& Pearce, N. (2005). A comparison of youth-driven and adult-driven youth programs: Balancing inputs from youth and adults. Journal of Community Psychology, 33, 57-74. (Need to review).

Lauver, S., Little, P., \& Weiss, H. (2004). Moving Beyond the Barriers: Attracting and Sustaining Youth Participation in Out-of-School Time Programs. Issues and Opportunities in Out-of-School Time Evaluation Number 6, 1-16.

Littel, J., \& Wynn, J. (1989). The Availability and Use of Community Resources for Young Adolescents in an Inner-City and a Suburban Community. The Chapin Hall Center for Children: Chicago.

Lochner, A., Allen, G., \& Blyth, D. (2009). Exploring the Supply and Demand for Community Learning Opportunities in Minnesota. Center for Youth Development, University of Minnesota Extension. 
Minnesota (MN) Youth Engagement Case Studies. (2008). Observations, focus groups and interviews with participants and staff of six successful long-term youth engagement programs around the state of Minnesota. Conducted by the University of Minnesota Extension Center for Youth Development in January-April, 2008.

Nakamura, J. (2001). The Nature of Vital Engagement in Adulthood. In M. Michaelson \& J. Nakamura (Eds.), Supportive Frameworks for Youth Engagement, New Directions for Child and Adolescent Development, Number 93, Fall 2001. New York: Jossey-Bass.

Noguera, P., \& Cannella, C. (2006). Youth Agency, Resistance, and Civic Activism, in Ginwright, S., Noguera, P., Cammarota, J. (Eds.). Beyond Resistance! Youth Activism and Community Change. New York: Routledge, pp. 333-347.

O’Donoghue, J.L., Kirshner, B., \& McLaughlin, M. (2002). Introduction: Moving youth participation forward, in New Directions for Youth Development, 96, pp. 15-26.

Pearce, N.J. \& Larson, R.W. (2006). How teens become engaged in youth development programs: the process of motivational change in a civic activism organization. Applied Developmental Science 10(3), pp 121-131.

Pittman, K., Wilson-Ahlstrom, A., \& Yohalem, N. (2003). After-school for all? Exploring access and equity in after-school programs. Out-of-School Time Policy Commentary. The Forum for Youth Investment.

Pittman, K., Martin, S., \& Williams, A. (2007, July). Core Principles for Engaging Young People in Community Change. Washington, D.C.: The Forum for Youth Investment, Impact Strategies, Inc.

Putnam, R.D., Feldstein, L.M., \& Cohen, D. (2003). Better Together: Restoring the American Community. NY: Simon \& Schuster.

Resnick, M.D., Bearman, P.S., Blum, R.W. Bauman, K.E., Harris, K.M., Jones, J., et al. (1997). Protecting adolescents from harm. Findings from the National Longitudinal Study on Adolescent Health, in The Journal of the American Medical Association, 278(10).

Saito, R.N. (2006). Beyond access and supply: Youth-led strategies to captivate young people's interest in and demand for youth programs and opportunities, in New Directions for Youth Development, 112, pp. 57-74.

Saito, R.N., Benson, P., Blyth, D., \& Sharma, A. (1995). Places to grow. Perspectives on youth development opportunities for seven- to 14-year-old Minneapolis youth. Minneapolis, Search Institute.

Scales, P.C., \& Leffert, N. (1998). Developmental assets: A synthesis of the scientific research on adolescent development. Minneapolis, MN: Search Institute.

Scales, P.C., Benson, P., Leffert, N., \& Blyth, D. (2000). Contribution of developmental assets to the prediction of thriving among adolescents. Applied Developmental Science, 4, 27-46. 
Scales, P.C., Roehlkepartain, E.C., \& Benson, P.L. (2009). Teen Voice 2009: The Untapped Strength of 15-Year-Olds. Minneapolis and Richfield, MN: Search Institute and Best Buy Children's Foundation.

Scales, P.C., Roehlkepartain, E.C., \& Benson, P.L. (2010). Teen Voice 2010: Relationships That Matter to America's Teens. Minneapolis and Richfield, MN: Search Institute and Best Buy Children's Foundation.

Search Institute. (2005). The Power of Youth and Adult Partnerships and Change Pathways for Youth Work. MI: WK Kellogg Foundation.

Simpkins, S., Little, P., \& Weiss, H. (2004). Understanding and measuring attendance. Issues and Opportunities in Out-of-School Time Evaluation. Number 7, 1-12.

Sipe, C.L. \& Ma, P. (1998). Support for youth: A profile of three communities. Philadelphia, Public/Private Ventures.

Sirianni, C., \& Friedland, L. (2001). Civic Innovation in America: Community Empowerment, Public Policy, and the Movement for Civic Renewal. Berkeley, CA: University of California Press.

Smith, C.S., Akiva, T., Arrieux, D., \& Jones, M.M. (2006). Improving quality at the point of service, in New Directions for Youth Development, 2006 (112), pp. 93-108.

Sullivan, T.K. (2011). Youth Engagement: More than a method. A way of life for healthy youth and community development. Unpublished manuscript for the Extension Center for Youth Development, Minneapolis, MN.

Verba, S., Scholozman, K.L., \& Brady, H.E. (1995). Voice and Equality: Civic Voluntarism in American Politics. MA: Harvard University Press.

Walker, J. (2006). Intentional youth programs: Taking theory to practice. in New Directions for Youth Development, 2006 (112), pp. 75-92.

Watts, R., \& Flanagan, C. (2007). Pushing the Envelope on Youth Civic Engagement: A Developmental and Liberation Psychology Perspective, Journal of Community Psychology, 35(6), pp. 779-792. (Need to review)

Weiss, H.B., Little, P. M., \& Bouffard, S.M. (2005). More than just being there: Balancing the participation equation. New Directions for Youth Development, No. 105, Spring, 2005.

Wheeler, W. (2007a). Youth Engagement: A Celebration Across Time and Culture, Framing the Issue. MI: W.K. Kellogg Foundation.

Wheeler, W. (2007b). Youth Engagement: A Celebration Across Time and Culture, Proceedings Summary. MI: W.K. Kellogg Foundation.

Yohalem, N., Wilson-Ahlstrom, A., \& Pittman, K. (2004). Participation during out-of-school time: Taking a closer look. Out-of-School Time Policy Commentary 7, March. 
Youniss, J., Bales, S., Christmas-Best, V., Diversi, M., McLaughlin, M., \& Silbereisen, R. (2002). Youth Civic Engagement in the $21^{\text {st }}$ Century. Journal of Research on Adolescence, $12(1)$.

Youniss., J., \& Hart, D. (2005). The intersection of social institutions with civic development. In L.A. Jensen \& R.W. Larson (Eds.) New Directions in Child Development: New Horizons in Developmental Theory and Research (Number 109) (pp. 73-81). San Francisco: Jossey-Bass.

Youniss, J., \& Yates, M. (1997). Community Service and Social Responsibility in Youth. IL: University of Chicago Press.

Zeldin, S. (2004). Youth as Agents of Adult and Community Development: Mapping the Processes and outcomes of Youth Engaged in Organizational Governance, in Applied Developmental Science 8(2), pp. 75-90.

Zeldin, S., Camino, L., \& Calvert, M. (2007). Toward an understanding of youth in community governance: Policy priorities and research directions. Analise Psicologica (2007), 1 (XXV): 7795.

Zimmerman, B.J. \& Campillo, M. (2003). Motivating Self-Regulated Problem Solvers. In. J.E. Davidson \& R.J. Sternberg (Eds.), The Psychology of Problem Solving. Cambridge, UK: Cambridge University Press.

(C) Copyright of Journal of Youth Development $~$ Bridging Research and Practice. Content may not be copied or emailed to multiple sites or posted to a listserv without copyright holder's express written permission. However, users may print, download or email articles for individual use. 